Evolving discourses on water resource management and climate change in the Equatorial Nile Basin

Authors:

Dr Nina Hissen**

Department for International Development (DFID)

Abercrombie House

Eaglesham Road

East Kilbride, UK, G75 8EA

Prof. Declan Conway

Grantham Research Institute on Climate Change and the Environment

London School for Economics and Political Science

Houghton Street

London, UK, WC2A 2AE 
Dr Marisa C. Goulden

School of International Development and Tyndall Centre for Climate Change Research

University of East Anglia

Norwich Research Park

Norwich, NR4 7TJ, UK

*Acknowledgements: The research was funded by the Tyndall Centre for Climate Change Research at the University of East Anglia, Norwich, UK.

Declan Conway is partly supported by UK NERC Grant Ref: NE/M020398/1.

The authors would like to thank the research participants in Kenya and Tanzania who contributed to the study.

** Views are those expressed of the author and do not reflect the official position of DFID. 


\begin{abstract}
Transboundary water resources management in the Equatorial Nile Basin (EQNB) is a politically contested issue. There is a growing body of literature examining water-related discourses which identifies the ability of powerful actors and institutions to influence policy. Concern about the effects of future climate change has featured strongly in research on the Nile River for several decades. It is therefore timely to consider whether and how these concerns are reflected in regional policy documents and policy discourse. This study analyses discourse framings of water resources management and climate change in policy documents (27, published between 2001 and 2013) and as elicited in interviews (38) with water managers in the EQNB. Three main discursive framings are identified which are present in the discourses on both subjects: a problem oriented environmental risk frame; and two solution oriented frames, on governance and infrastructure development. Climate change discourse only emerges as a common topic around 2007. The framings found in the water resources management discourse and the climate change discourse are almost identical, suggesting that discursive framings were adopted from the former for use in the latter. We infer that the climate change discourse may have offered a less politically sensitive route to circumvent political sensitivities around water allocation and distribution between riparian countries in the EQNB. However, the climate change discourse does not offer a lasting solution to the more fundamental political dispute over water allocation. Moreover, in cases where the climate change discourse is subsumed within a water resources management discourse there are dangers it will not fully address the needs of effective adaptation.
\end{abstract}


Biographical sketch

Nina Hissen is a Livelihoods Adviser for the Department of International Development (DFID). Prior, Nina worked as a researcher on various topics, among others the influence of climate change on migration, and water governance. Nina holds a $\mathrm{PhD}$ in International Development from the University of East Anglia, Norwich, UK.

Declan Conway is a Professorial Research Fellow at the Grantham Research Institute, conducting research on water security, climate change, and the water-energy-food nexus. Originally a geographer, Declan draws on insights from different disciplines to pursue problem focused research. He has over 20 years experience working in sub-Saharan Africa (particularly the Nile Basin countries) and Asia (particularly China).

Marisa Goulden is a Lecturer in the School of International Development, at the University of East Anglia. She researches and teaches on topics related to adaptation to environmental change and extreme events, water security, livelihoods and resilience with research experience in Sub-Saharan Africa and the UK.

\section{Evolving discourses on water resource management and climate change in the Equatorial Nile Basin}

\section{Introduction}


Transboundary water resources management in the Equatorial Nile Basin (EQNB) is a politically contested issue. Disputes over water allocation between the Nile Basin's downstream riparian countries (Egypt and Sudan) and upstream riparian countries (Ethiopia, South Sudan, Uganda, Kenya, Tanzania, Rwanda, Burundi, and Democratic Republic of Congo (DRC)) are an important feature of water resources development in the EQNB. The 1959 Nile Waters Agreement, from the colonial period, which allocates Nile water between Egypt and Sudan, has in recent years been challenged by the upstream riparian countries (Cascao, 2008). Since 2010, a new agreement to manage water in the Nile Basin, the Cooperative Framework Agreement, has been opened up for signature. The signing of this treaty by six of the Nile riparian countries, and its rejection by Egypt and Sudan shows that political divides over transboundary water remain at the core of water resources management (WRM) in the basin.

The availability of and access to water are important prerequisites for social and economic development in the Nile Basin. A growing industrial sector, increase in irrigated agriculture and rise in population and living standards across the Nile Basin are increasing demand for water (NBI, 2012). Despite economic growth, about $80 \%$ of the Nile Basin's population is still employed in the agricultural sector (CIA, 2015) and their livelihoods are closely linked to water access and availability. Drought events such as in 2011 in East Africa and 2015 in Ethiopia show that rainfall variability continues to exert a dramatic effect on livelihoods and food security in parts of the Nile Basin (The Guardian, 2011, 2016). The seven riparian countries (Uganda, South Sudan Kenya, Tanzania, Rwanda, Burundi, and DRC) have a combined population of 338 million, and are home to about $30 \%$ of Africa's population (United Nations, 2015). 
Climate change is expected to affect water availability in the Basin. Africa as a continent is generally held to be one of the regions most vulnerable to anthropogenic climate change, due to its high exposure and low adaptive capacity (Boko et. al., 2007; Niang et al., 2014). Climate models project increased heavy rainfall events in East Africa and amplification of existing water stress as a likely consequence of climate change (Niang et al., 2014). These factors are likely to lead to changes in river flow characteristics (Milly, Dunne, \& Vecchia, 2005) and a possible increase in the frequency or intensity of droughts (Seneviratne et al., 2012).

Discourses encompass discursive frames around specific issues, e.g. WRM. Discursive frames are 'ever-changing 'scripts' for organising and understanding the social and political world' (Dayton, 2000, pp. 72-73). Discursive frames 'are transmitted via language and are constructed through social interaction, reaction, and adjustment' (Ibid.). The study of environmental discourses is an established field. Prominent studies have examined the alteration in attitudes and opinions within international discourse on ozone depletion (Litfin, 1994), traced the development of policy discourses on acid rain in the UK and the Netherlands over the 1980s and 1990s (Hajer, 1995), and reflected on the plurality of competing and complementing international environmental discourses and their connection to the industrialisation paradigm over time (Dryzek, 2013).

There is a growing body of literature examining water-related discourses often with a focus on Integrated Water Resources Management (IWRM) and its influence on policy making (Biswas, 2004; Molle, 2008; Saravanan, McDonald, \& Mollinga, 2009). Further, discourse analysts are interested in the study of securitization of water resources (Buzan, Wæver, \& Wilde, 1998; Gerlak \& Mukhtarov, 2016; Lankford, Bakker, Zeitoun, \& Conway, 2013; Stetter, Herschinger, Teichler, \& Albert, 2011; Warner, 2011; Zeitoun \& Warner, 
2006). Political discourse around climate change is a strongly contested issue predominantly framed as an environmental crisis (Boykoff, 2008; Doulton \& Brown, 2009; Hulme, 2009), but also raising questions around human security and vulnerability (O'Brien, Eriksen, Nygaard, \& Schjolden, 2007).

Convergence of values attached to the environment can be observed in global environmental discourses. Most global environmental discourses share similar discursive framings, namely that the environment is framed as in a state of crisis, which presents a threat to society and the economy. Solutions to address and prevent such crises are offered by institutional reform and financial investments (W. Neil Adger, Benjaminsen, Brown, \& Svarstad, 2001). Such global discourses often result in a 'best-practice' approach, which suggests common solutions to a diverse range of local problems in very different local contexts. In this way global environmental discourses influence local decision-making by creating, as well as limiting, choices for policy outcomes.

Powerful actors and institutions, like the Nile Basin Initiative (NBI) and the Lake Victoria Basin Commission (LVBC), are able to influence policy discourses, and at the same time are a product of other discourses themselves (Hajer \& Versteeg, 2005). These policy actors produce discourses, which are then reproduced by other actors, leading to the forming of discursive policy coalitions. While some powerful actors are enabled through the institutional structure and thus manage to shape and influence the discourse, the discursive structure presents a constraint for others, limiting the discourse to certain perspectives and views (Hajer, 1995, p. 49). Powerful actors may try to influence a discourse and shape it to match their interests; thus analysing policy discourses can help to reveal interests and political power struggles. 
Climate variability and discussion about the effects of future climate change have featured strongly in research and scholarship on the Nile Basin for several decades (Gleick, 1991; Hulme, 1990); it is therefore timely to consider whether and how these concerns are reflected in regional policy documents and policy discourse. In this context, we examine how political discourses over WRM have reacted to the threat of climate change and its potential impacts. Despite the importance of discourses for political decision making (Hajer \& Versteeg, 2005), and the challenge of climate change for transboundary WRM, we know little about how water managers are beginning to frame the issue of climate change, how this framing is mediated by existing frames, and any emerging implications for decisions over contested water resources in the EQNB. We seek to address this gap by asking; how do water managers frame climate change compared with existing framings of WRM in the EQNB, and what are the implications for adaptation?

This study analyses speech-acts as published in policy documents and elicited through interviews with water managers in the EQNB as evidence of discourse. The analysis compares discursive framings of WRM and climate change used by key actors who shape water management in the EQNB. These include the NBI and the LVBC (intergovernmental institutions), national governments of riparian countries, and other relevant stakeholders. We begin with a brief introduction to the context of WRM and the nature of the climate change challenge for water availability in the EQNB. The research methods, data sources, and research findings are then presented. We conclude with a discussion of the discourse framings in the wider political context of the EQNB and their implications for adaptation to climate change in the basin.

\section{Climate change and water resources in the Equatorial Nile Basin}


The EQNB comprises a major part of the Nile Basin, encompassing $650000 \mathrm{~km}^{2}$ and stretching from central Burundi and northern Tanzania in the south, to central South Sudan in the North, including Lake Victoria with its tributaries (Figure 1). The EQNB contributes less than $30 \%$ annually to the main Nile flow measured at Lake Nasser, via the White Nile (El Bastawesy, Gabr, \& White, 2013). The White Nile's main water source is Lake Victoria, which gains more than $80 \%$ of its water from direct rainfall (Di Baldassare et al., 2011). The Lake's level has exhibited high variability in response to rainfall variation and extreme rainfall events (Conway, Allison, Felstead, \& Goulden, 2005) and also more recently due to management factors, such as regulation of lake outflows for electricity generation (Conway, 2005; Sutcliffe \& Petersen, 2007). The other $20 \%$ of the water inputs to the lake derive from tributary inflows, including the Kagera and Mara Rivers. 


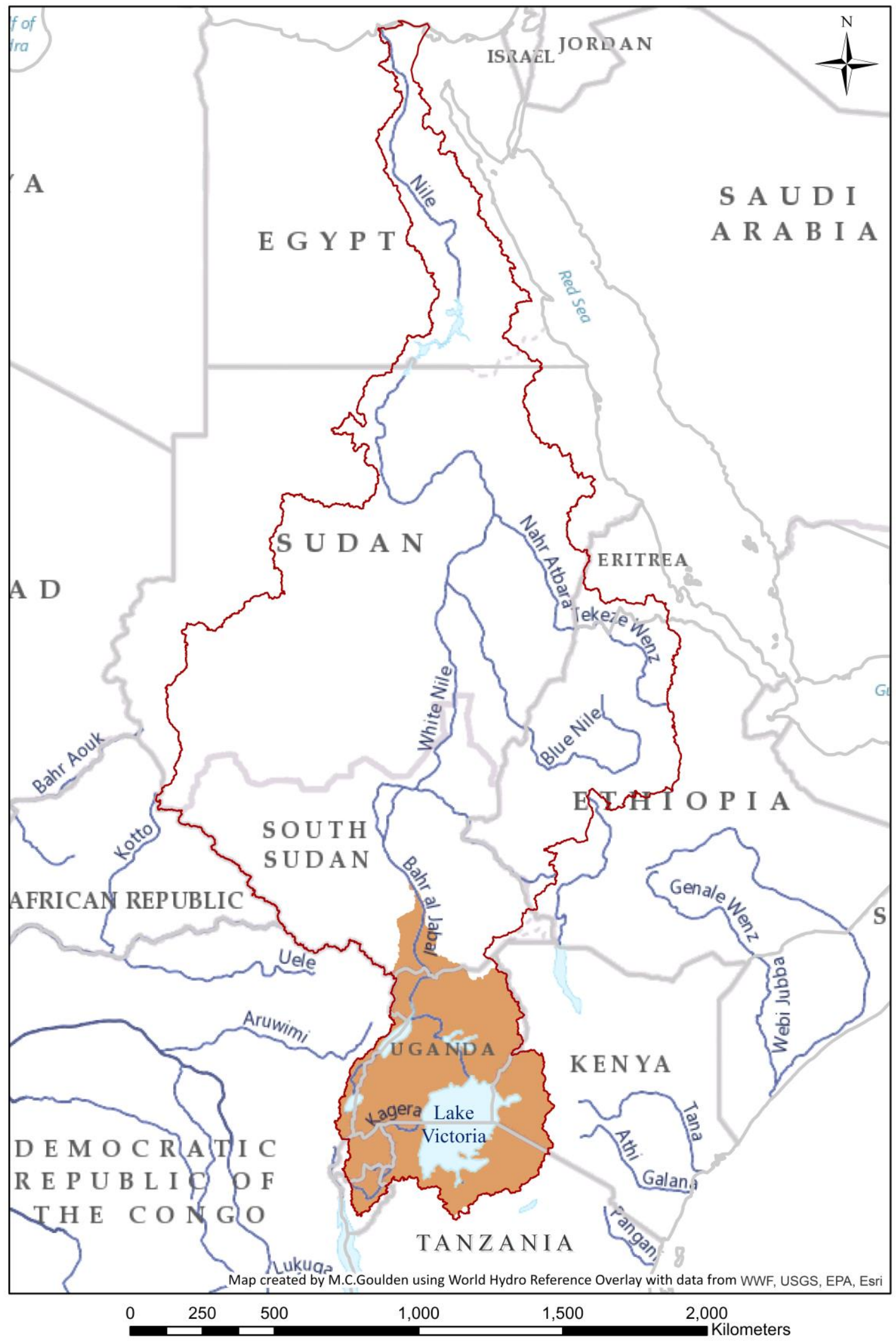

Figure 1: Map of the Nile Basin (boundary shown in red) showing the location of the Equatorial Nile Basin (shown in orange). 
The climate in the riparian countries of the EQNB encompasses semi-arid, tropical and subtropical zones. Rainfall patterns are characterised by marked seasonality and interannual variability (Conway et al., 2009) and are strongly influenced by the El Niño-Southern Oscillation (ENSO) (Beyene, Lettenmaier, \& Kabat, 2010). There is evidence that rainfall patterns in the Lake Victoria region/EQNB have changed since 1960. An increase in overall rainfall in the basin has been observed, with higher rainfall during the short rains from October to December (Kizza, Rodhe, Xu, Ntale, \& Halldin, 2009).

The detail of future climate change and its implications for lake levels and river discharge in the EQNB remain highly uncertain (Conway et al., 2009; Di Baldassare et al., 2011; Taye, Willems, \& Block, 2015). Whereas the frequency of heavy rainfall events is likely to increase in many locations globally, projections of changes for specific locations in the Nile Basin remain highly uncertain (Kundzewicz et al., 2014). For example, Christensen et al. (2007) review different global climate models (GCMs) and find a model average of a 7\% increase in annual rainfall in East Africa, although the individual model results ranged from a decrease of $3 \%$ to an increase of $25 \%$. A recent study of the Mara River basin using five GCMs showed an increase in flow projections by the mid to late $21^{\text {st }}$ Century, with wetter wet seasons and drier dry seasons (Dessu \& Melesse, 2013). Such differences, between individual GCM projections and between their ensemble mean changes over time, underscore the high level of uncertainty about the detail of the climate change threat. This propagates into severe challenges for policymakers and water managers to interpret what the implications for action might be.

Climatic conditions and their effects on discharge of Nile tributaries are an important factor in the context of hydropolitics and water allocation in the EQNB (Elhance, 1999). There are many examples of transboundary African rivers and lakes where climate variability has 
compromised water management and exacerbated competing national water needs (Zeitoun, Goulden, \& Tickner, 2013). These include the prolonged sequence of low rainfall and Blue and Main Nile discharge during the 1980s (Conway, 2005) and declining level of Lake Victoria between 2000 and 2006 (Goulden \& Conway, 2008). Riparians may factor in observed rainfall data for calculating water available in a basin and use this when negotiating water allocation in a transboundary river basin (Goulden, Conway, \& Persechino, 2009).

\section{Material and methods}

In this study, speech-acts between 2001 and 2013 were examined. These included documents as well as semi-structured interviews with policymakers in the EQNB. Speechacts were analysed inductively, and patterns that emerged during the analysis were recorded and subsequently interpreted in the wider political context of the Nile Basin. Documents are understood to present the official standpoint of key actors and organisations in the sector such as government departments and international and transboundary organisations. The discursive frames resulting from the document analysis illustrate the formal or official framing of the discourse. Documents were selected based on their technical and geographical relevance for WRM in the EQNB and included policy documents and technical reports (full list in Annex I). Only documents with a clear focus on WRM in EQNB countries were considered and out of a total sample of 162 documents, 46 were initially selected. Documents were qualitatively assessed by importance for policy making and only documents, which were assessed as medium to high importance were included in the analysis. This reduced the sample size to 27 documents, which were 
analysed in regards to their discursive framings of WRM and climate change. Based on Potter and Wetherell (1994) the discourse analysis included the three following features:

- $\quad$ The content and form of the document;

- the action, construction and variability of the document, i.e. actions that people perform through their writing which in turn construct a discourse, but which vary depending on the actor (different actors may give a subject different meaning);

- $\quad$ The rhetorical and argumentative organisation of a text or speech act in order to uncover how the discourse is framed to compete with alternative framings.

The frames identified from the document analysis were then analysed in relation to the perceptions of decision-makers identified for interview. A total of 38 semi-structured interviews were conducted (full list in Annex II). In the interviews, participants were asked about their personal views of WRM and to note important challenges in WRM in the EQNB. Participants were also asked about their personal perceptions of climate change and its impacts and consequences for sustainable WRM and adaptation.

The participants included policymakers, experts and practitioners based in the region, identified through initial contacts and augmented through a snowball sampling process. Personal opinions and insights offer a different interpretation of the policy documents, adding important contextual information, which enables a more nuanced appraisal of the formal texts. While formal policy documents are understood to represent a more abstract and higher level discourse, the data from interviews can reveal insights into day-to-day policy issues and thus a more practical and applied perspective on water management.

\section{Results}


This section presents the results of the analyses of the WRM (4.1) and climate change (4.2) discourses. An inductive approach was used for the analysis of each discourse by carefully reviewing the documents, identifying framings and coding them using the software NVivo. Similar framings were then grouped, and the process was repeated twice. This process ensured that the essence of each framing was captured and avoided significant duplication within the framings finally selected. This resulted in three aggregated discursive framings identified in the documents, which were present in the discourses on both WRM and climate change. The three framings were (1) an environmental risk frame, 2) a governance frame, and 3) an infrastructure development frame. The interview data were then analysed using the coding developed from the document analysis.

Despite many academic papers on climate change in the Nile Basin since the early 1990s, climate change discourse only emerges as an important topic for WRM in the EQNB around 2007, gaining more traction since 2010 (Figure 2). The rather unusually high appearance of the term 'climate change' in 2010 is due to two important documents, which were both published that year: Kenya's National Climate Change Response Strategy and the Strategic Plan by Kenya's National Environment Management Agency. Both documents frequently mention climate change, with the National Strategy specifically honing in on the issue.

The framings found in the WRM discourse and the climate change discourse in the EQNB are almost identical, suggesting that discursive framings were adopted from the WRM discourse for use in an emerging climate change discourse. Both discourses show similar discursive patterns, which identify problems and suggest solutions. For example, environmental risks (e.g. floods and droughts) are framed as key challenges to human livelihoods. Solutions and mitigation mechanisms for these risks are framed most often around improving governance and sometimes infrastructure. Whereas both solution 
frames are used in the WRM and the climate change discourse, the infrastructure framing is rarely used in the climate change discourse. The following sections present the framings in more detail.

[Insert figure 2 - 'Word frequencies WRM and climate change' - here]

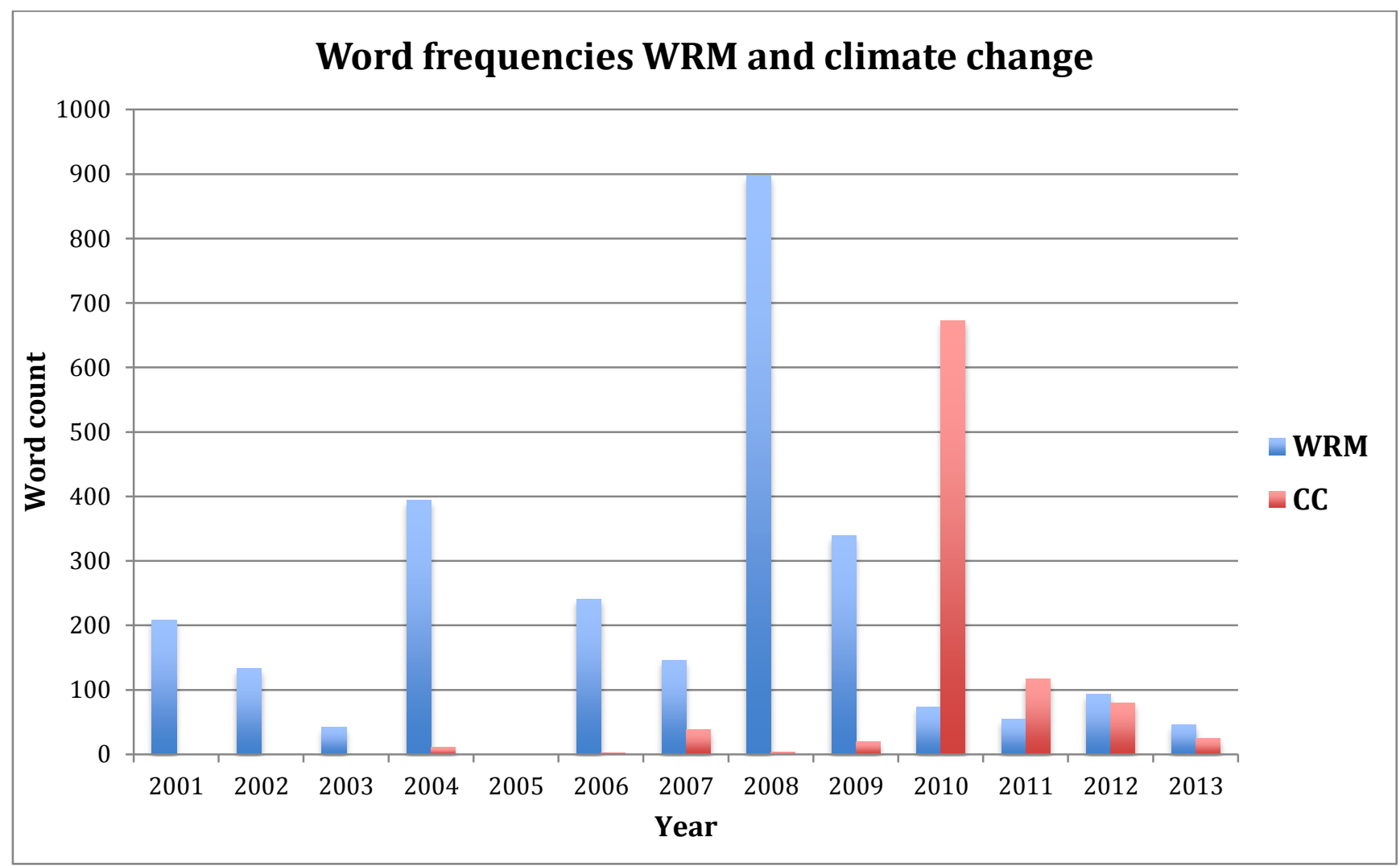

Figure 2: Normalised word frequencies for the terms 'water resources management' (WRM) and 'climate change' (CC) compared in analysed documents published between 2001 and 2013 (Annex I, N = 27).

\subsection{Discursive Framing of Water Resources Management}

The WRM discourse frames natural events, such as floods and droughts, as environmental risks and threats to human livelihoods. To mediate these risks, WRM is framed as a 
solution to protect catchment areas to prevent and reduce environmental degradation and its negative effects on livelihoods. As specific measures to achieve these aims, the WRM discourse proposes improving governance and development of infrastructure as the main solutions to the problem.

The two solution frames present a range of policy choices for decision-makers. The governance framing combines three elements of governance which can be enhanced through: 1) strengthening transboundary cooperation among EQNB riparian countries and benefit sharing; 2) decentralization of WRM, transferring authority from the national to the local level; and 3) enhanced participation in WRM by local communities, for example through Water User Associations. The infrastructure development frame centres on improving water storage, irrigation systems and hydropower development in order to reduce the risks from floods and droughts, and improve resilience of peoples' livelihoods. Table 1 lists examples of text from documents to demonstrate the main themes identified in the discourse analysis.

[Insert table 1 - 'Examples of discursive frames' - here]

Frames

Environmental risk frame

\section{Discourse}

Water Resources
Management Floods and droughts are framed as a risk to humans and livelihoods.

Climate Change - Climate change impacts are framed as an environmental threat putting livelihoods at risk.

\section{Examples}

'Prolonged drought, coupled with the appalling state of the major water catchment areas, has caused drying up of rivers, springs and other water bodies. This state of affairs has caused crop failure and decimation of livestock units as well as wild animals thereby creating a state of famine and hopelessness to many ordinary Kenyans in the rural areas.' (WRMA, 2009a, p. i)

'Climate change is a serious threat, with potentially very adverse impacts on the socioeconomic conditions in the Nile Basin, on its environment, and on the on-going efforts to establish mutually agreed upon mechanisms to manage the shared Nile water resources.' (NBI, 2012, p. 207) 


\section{Governance}

frames

Cooperation

Decentralisation

Water Resources

\section{Management}

Decentralisation is framed as a positive reform of the water sector, which is intertwined with participation of local stakeholders in WRM.

\section{Climate Change}

\section{Participation}

Infrastructure Development frame
Water Resources Management - Participation framed as bringing positive change to communities.

\section{Climate Change}

Water Resources Management
'The level of cooperation has visibly improved from initial weariness to a strong and mutual sense that the cooperation is valuable and that it produces tangible, beneficial results.' (NBI, 2012, p. 2)

"Climate-change adaptation measures will be most effective when undertaken in coordination with other riparians. Examples of joint measures to enhance the collective adaptive capacity include coordinated reservoir operation, promoting agricultural trade amongst the countries and between the basin and other regions, interconnecting power and transport systems, developing joint mechanisms for resource solicitation for climate-change programmes, and conducting joint research." (NBI 2012, p. 206)

'The success of the on-going water sector reforms is dependent on effective collaboration between all players in the sector. The Ministry is in the process of developing a comprehensive stakeholder mobilization and participation strategy that will seek to enhance the effective participation of all key stakeholders in water sector activities and generate consensus on the sector reform agenda and the implementation approach. [...] Decentralization of water resource management institutions is slowly entrusting the management of water resources to communities and the private sector.' (WREM, 2008, p. 74)

No framing was found, that linked climate change to decentralisation in the Equatorial Nile Basin.

'Positive change at the community/society level is not dependent on the level of investment but on local governance and community participation.' (LVBC, 2011, p. 8)

No framing was found, that linked climate change to stakeholder participation in the Equatorial Nile Basin.

'... current water storage levels [are] low and need to be increased to meet the growing demand for water.' (WRMA, 2009b, p. 6) 
'In order to successfully adapt to CC different measures are needed than before, e.g. the way of constructing bridges, dams, water wells, even houses must change and include the projected impacts of climate change, e.g. cyclones, different level of rainfall. Business as usual won't manage that.' TZGov(b)

As Table 1 shows, the discourse analysis found a strong overlap in framing between the two discourses. Most frames, which were found in the WRM discourse, were also found in the climate change discourse. Due to the development of discourses over time, and the later emergence of the climate change discourse, it appears that the discursive framings were first developed in relation to WRM and then adopted for use in the climate change discourse.

The infrastructure development frame was common in WRM policy documents. The discursive arguments point to the inadequacy of the infrastructure to address shocks such as flooding and drought, which are argued to be disrupting water services and electric power and are further aggravated by climate change. The framing highlights investments in energy production and transmission infrastructure as successfully facilitating transboundary cooperation. The framing suggests a linear trajectory to solve WRM problems exacerbated by climate change - investing in more and better infrastructure will solve issues around WRM. The logic of the framing goes as follows: the higher the financial investment, the greater the amount of infrastructure projects built, the better and more effectively WRM issues will be addressed, the more benefits will be derived, which can be shared amongst riparians, thus reducing political tension and enhancing cooperation. This framing was present in documents by the Kenyan and Tanzanian governments, as well as 
the NBI and the World Bank (Government of Tanzania, 2008; NELSAP, 2012; World Bank, 2004; WRMA, 2009b).

There is evidence, however, that there is competition between the two frames of infrastructure development and improved governance. Whereas the NBI forms a discourse coalition with parts of the Kenyan and Tanzanian governments, and the World Bank, by utilising the infrastructure development framing in their policy documents, the LVBC promotes a different view, one that emphasises the importance of governance. For example, the LVBC's Strategic Plan points out under 'Lessons learned':

'Positive change at the community/society level is not dependent on the level of investment but on local governance and community participation.' (LVBC, 2011, p. 8)

These differences of either promoting the governance framing or advocating mainly infrastructure development as solutions to environmental risks were also reflected in interviews. Where participants emphasised the importance of improved governance for achieving better water management, the framing of infrastructure development tended to be less prominent. Overall, participants from policy networks forming around the LVBC preferred the governance framing over the infrastructure framing (Hissen, 2014). While this points towards two discourse coalitions within the EQNB, the differences are relatively subtle and both subscribe to the dominant discourse on WRM.

Mosse and Lewis (2006) observe how policy organizations, such as the NBI or LVBC, act as governance brokers and translate governance processes into policy implementation namely via establishing and maintaining interpretations of reality, or in other words creating and sustaining discourses. As argued above, policymakers define and sustain interpretations of reality via framing policy discourses. When a discursive frame becomes 
dominant and is consequently institutionalized, these interpretations of reality are translated into policies and development projects and thus directly impact policy practice, as seen in the EQNB (as discussed in section 5).

\subsection{Discursive Framing of Climate Change}

Most of the discursive frames observed in the WRM discourse were also used in relation to climate change. In policy documents climate change is framed as exacerbating environmental risks, and consequently threatening sustainable development (EAC, 2011; Government of Kenya, 2010; NBI, 2012; Nile Basin Development Forum, 2011; United Republic of Tanzania, 2007). This framing is found at all policy levels in WRM documents by regional actors such as the NBI and the LVBC to those of national governments, donor agencies, NGOs and local water management groups (EAC, 2011; Government of Kenya, 2010; Government of Tanzania, 2008; LVBC, 2011; MRWUA, 2011; NBI, 2012; Nile Basin Development Forum, 2011; SIDA, 2010; USAID, 2013).

Climate change is commonly framed in the same context as other environmental risks such as environmental degradation, soil erosion, deforestation, pollution, etc. (NEMA, 2010). In documents and interviews there is a direct association between climate change impacts and water resources and changes in the quantity and timing of water availability (Government of Tanzania, 2002; Nile Basin Development Forum, 2011) e.g. higher evaporation and evapotranspiration, increased frequency and intensity of floods and drought, higher air and water temperatures (with various negative consequences such as an increase in water-borne diseases), sea level rise and melting glaciers (NBI, 2012). This extensive list represents highly generalised physical climate change impacts, and most water policy documents simply refer to the 'adverse impacts of climate change', stating that 
climate change is a concern that should be addressed (EAC, 2011; Government of Kenya, 2013; Government of Tanzania, 2008; LVBC, 2011). There is a marked absence of specific examples of the kinds of hazards, impacts and consequences that climate change could bring to inform and justify policy responses.

In policy reports and interviews alike, climate change is framed as harmful for the people living in the EQNB. For example, one interviewee from the Kenyan government remarked:

'[Climate change] will really spoil this economy, and if we don't check it we are dead, all of us. All of the East African community will die - socially and even economically.' (KE Gov(a))

To address threats posed by climate change, the discourse suggests improved governance and investment in infrastructure. Improved governance measures such as well-designed policies, functioning institutions and technical capacity-building are advocated in policy documents and by interviewees. Phrases such as 'no-regret' measures, 'climatemainstreaming', and 'climate-proofing' development projects are used to describe approaches to address climate change in the water sector. The NBI defines 'no-regret' measures as actions:

'that build resilience to current climate variability while enhancing adaptive capacity.' (NBI, 2012, p. 218)

'No-regret' measures placed within the frame of improved governance include greater cooperation between the Nile riparian countries, enhancing the integration of markets in the region and fostering intra-basin trade to create shared benefits, and strengthening human and institutional capacity at national and local levels. This framing mirrors 
measures supported under the WRM discourse to improve transboundary water management.

It is interesting to observe, that the climate change framing mirrored the WRM to a large extent (Table 1). The climate change discourse framed environmental risks (or the exacerbation of these through climate change) as a key challenge to human livelihoods, and framed improved governance and infrastructure as solutions to the challenge. However, the details of the framing around governance varied from the WRM discourse. Whereas there was a strong emphasis on improving transboundary cooperation to enhance adaptation to climate change in the basin, decentralisation and participation at a local level were not seen as important solutions to the challenge. These two aspects were hardly present in the climate change discourse in the EQNB. This is surprising, as climate change adaptation will need to be implemented across different policy levels and scales, and its success will in-part depend on the capacity of local government and communities to adapt to environmental change (W Neil Adger, Arnell, \& Tompkins, 2005).

In terms of developing infrastructure, the climate change framing centres on increasing water-storage capacity and hydropower production and investing in power transmission lines (NBI, 2011, 2012; NELSAP, 2012). Once more the same measures are mentioned as those in the discursive framing on infrastructure development on WRM. This suggests that water managers in the EQNB view climate change from the same perspective as other water-related challenges. The dominant discursive logic is that climate change exacerbates pre-existing WRM challenges and hence the measures proposed under the WRM are generally considered adequate to address climate change. This logic is widely accepted in the EQNB and spans the two discourse coalitions centred on the NBI and the LVBC. 


\section{Discussion - Hydropolitics and Adaptation Practice}

This study has examined the political discourse around WRM and climate change in the EQNB. Climate change is highly likely to influence water availability and thus livelihoods in the years to come, yet while policymakers are aware of the issue, conviction in its importance seems limited. Several respondents identified the 'real issue' in the Nile Basin as the allocation or re-allocation of water among the riparian countries. This has been particularly manifest in negotiations on the Cooperative Framework Agreement which have resulted in a widening of the political divide between upstream and downstream (namely Egypt and Sudan) riparians, and has become even more topical with the on-going construction of the Grand Ethiopian Renaissance Dam on the Blue Nile in Ethiopia (Cascão \& Nicol, 2016; El Bastawesy, Gabr, \& Mohamed, 2015; Keith, Epp, Houghton, Lee, \& Mayville, 2014).

Discourse analysis showed some differences between the framings in policy documents and concerns voiced by policy-makers in interview. Whereas views in interviews were consistent with the perception in documents of climate change as an environmental risk, which needed to be addressed through governance reforms (including improved cooperation) and infrastructure (e.g. KE NGO1, INGO2 (a), INGO2 (b)), the interviews raised additional interests. Interview results revealed three dominant subject areas: 1) climate change, 2) diplomatic relations in the Nile and EQNB, and 3) available finance. The climate change theme was split into three components: Firstly, how much money was available (and from whom) to finance projects on WRM adaptation, and to reduce anticipated impacts of climate change. Secondly, reflections on the diplomatic relations of riparian countries in the EQNB, and jointly managed projects on WRM (participants often had a positive focus, omitting any difficulties of working together). In particular, 
policymakers emphasised that to improve climate change adaptation riparian countries needed to work together as the impacts were cross-boundary. This resonates with the cooperation framing identified in documents (Section 4.1). Thirdly, interviewees focussed on how to finance WRM, in particular for the construction of water infrastructure. Water managers were very concerned about future water availability in the EQNB. Interviewees already experienced a rise in demand for water and expected that demand would continue to rise, while climate change was likely to reduce the amount of water available in the future. Therefore, their main concern was how to guarantee adequate water supply and finance necessary water infrastructure, such as for water storage.

In the interviews overall, there was a strong focus on finance, which was not found to the same extent in policy documents. While some policy documents mentioned financial concerns, this issue was only mentioned as part of the infrastructure development framing, and did not emerge as a stand-alone frame. The theme around financing, however, seems to provide a 'missing link' between the two discourses on WRM and climate change. As previously shown, there is an overlap between the solution frames in both of the discourses on WRM and climate change. For example, for climate change adaptation, similar measures are proposed to those for WRM, e.g. enhancing water storage capacity. Whereas financing concerns are widespread in the Nile Basin and often seen as a constraint to development in the African context (Decalo, 1992), in recent years donor countries have made pledges to invest heavily in financing climate change adaptation in Least Developed Countries (W. Neil Adger, Huq, Brown, Conway, \& Hulme, 2003; Caravani, Barnard, Nakhooda, \& Schalatek, 2014). Policymakers in the EQNB are aware of this, and have already started to re-frame existing water management projects. For example, a large programme funded by the World Bank in 2012, which had previously been discussed as a 
programme extension for enhancing cooperation over WRM in the Nile Basin, was reframed in its extension phase as one for improving climate resilient growth (World Bank, 2012). The interventions proposed under the new framing were identical to the interventions proposed under the previous programme, including enhancing cooperation between riparians by investing in institutional capacity, jointly managed water resources planning and activities, and promoting investments in the region.

To explain this observation of rising awareness of climate change and a shift in the discourse, the development of hydropolitics in the Nile Basin needs to be taken into account. The history of hydropolitics in the Nile Basin is rooted in questions about the distribution, allocation and use of water and is thus closely intertwined with water security concerns (Waterbury, 2002). Interventions, which are mentioned as part of the solution frames in the WRM and climate change discourses (namely increasing water storage and addressing water related hazards), would also benefit water security in the EQNB. However, hardly any reference to 'water security' was found in policy documents. Instead, these interventions were predominantly framed in the context of adapting to climate change. In a few cases participants did relate better water infrastructure to 'being watersecure' (Hissen, 2014). The few speech-acts which explicitly refer to water security, only used the infrastructure development frame, omitting the governance frames.

Given the politically sensitive context and the political deadlock over the Cooperative Framework Agreement negotiations, it is unsurprising that the term 'water security' is rarely mentioned in the WRM discourse unlike climate change. Some of the differences may also result from the more restricted use of the term water security until the mid to late 2000s. Policymakers in the EQNB may use framings around climate change instead of water security, as they are much less politically sensitive (Nicol \& Cascao, 2011). This 
strategy seems to be constructive to circumvent the political deadlock over the Cooperative Framework Agreement. It appears that the climate change discourse offers a less politically sensitive avenue for organisations such as the NBI or the LVBC (and its member states) to discuss transboundary WRM issues and prepare and implement technical responses, which involve governance reform and infrastructure development. This framing also to some extent externalises the problem and also makes it accessible to new funding opportunities as the international donor community has increasingly financed climate change adaptation and mitigation, thus motivating a move towards climate change as a new source for funding WRM related projects.

The discursive strategy used by water managers in the EQNB has potentially contributed to the continuation of cooperation over transboundary WRM during relatively tense hydropolitical times. However, the strategy does not address directly the roots of the tension over water security; it has not resolved the 'real issue', namely the re-allocation of water rights. Furthermore, using the climate change discourse as a substitute to address WRM challenges, limits policymakers from fully addressing climate change impacts, which are not entirely covered by WRM concerns. For example, while policymakers often referred to climate finance, impacts and adaptation in the interviews, they rarely mentioned specific adaptation measures. In another example, the previously mentioned World Bank funded programme (World Bank, 2012), re-framed as 'climate resilient', retained the original objective of transboundary-cooperation. However, among other things adaptation of WRM to climate change also requires changing practices at local scales through strong engagement with local governments and communities. As this study found, the governance framing in the climate change discourse centred on transboundary cooperation, but was silent on decentralisation and stakeholder participation. To adapt to climate change by 
making WRM more resilient, it can be argued that the framing of the discourse needs to include a stronger focus on decentralisation and participation, with local government and communities involved in design and implementation.

Even though policymakers highlighted their efforts to 'climate-proof' development projects and infrastructure, it is unclear whether such approaches (and their implementation) are sufficient to adapt effectively to climate change or whether some proposals represent cases of maladaptation (Barnett \& O’Neill, 2010). For example, building infrastructure such as dams for hydropower and irrigation expansion may increase exposure to droughts (leading to electricity load-shedding) and longer-term water scarcity. This can also contribute to land-use change, which in turn may deplete carbon sinks (Cooley, Christian-Smist, Gleick, Allen, \& Cohen, 2009; Gleick et al., 1997). Effective 'climate proofing' requires stress-testing infrastructure and management systems and incorporating flexible and forward-looking decision-making processes to address uncertainty in climate change impacts alongside non-climatic changes.

\section{Conclusions}

The emergent discourse on climate change in the EQNB forms an extension of the discourse on WRM. Three discursive frames were identified in both discourses: (1) an environmental risk frame, 2) a governance frame(s), and 3) an infrastructure development frame. The environmental risk frame was widely used to describe the nature of the problem; improving governance and developing infrastructure were frames used to present solutions. Discourse analysis showed some differences between the framings in policy documents and concerns voiced by policy-makers in interviews. These revealed climate 
change, diplomatic relations in the EQNB and more widely in the Nile Basin, and availability of finance as dominant subject areas.

A climate change discourse in the EQNB only really emerged after 2007 and is similar to the WRM discourse. This suggests the language and main elements of the climate change narrative have been largely adopted from the WRM discourse. We infer that the climate change discourse may offer a less politically sensitive route to circumvent the political sensitivities around water allocation and distribution between riparian countries in the Nile Basin, to allow continued transboundary cooperation over water. However, the climate change discourse does not offer a lasting solution to the more fundamental political dispute of water allocation. Moreover, the climate change discourse is highly generalised and if it remains subsumed within a WRM discourse there are dangers it will not fully address the needs of effective adaptation. A more nuanced and less derivative discourse on adaptation would recognise among other things the need to decentralise adaptation efforts, and encourage participation of local governments and communities in the design and implementation of adaptation programmes.

\section{Annex I}

\begin{tabular}{|l|l|l|l|}
\hline Type of Actor & Organization/ Actor & Document Title & $\begin{array}{l}\text { Type of Document/ } \\
\text { Date }\end{array}$ \\
\hline Multilateral & East African Community & Second Development & Strategic document, \\
regional actors & $(E A C)$ & Strategy, 2001-2005 & 2001 \\
\hline
\end{tabular}




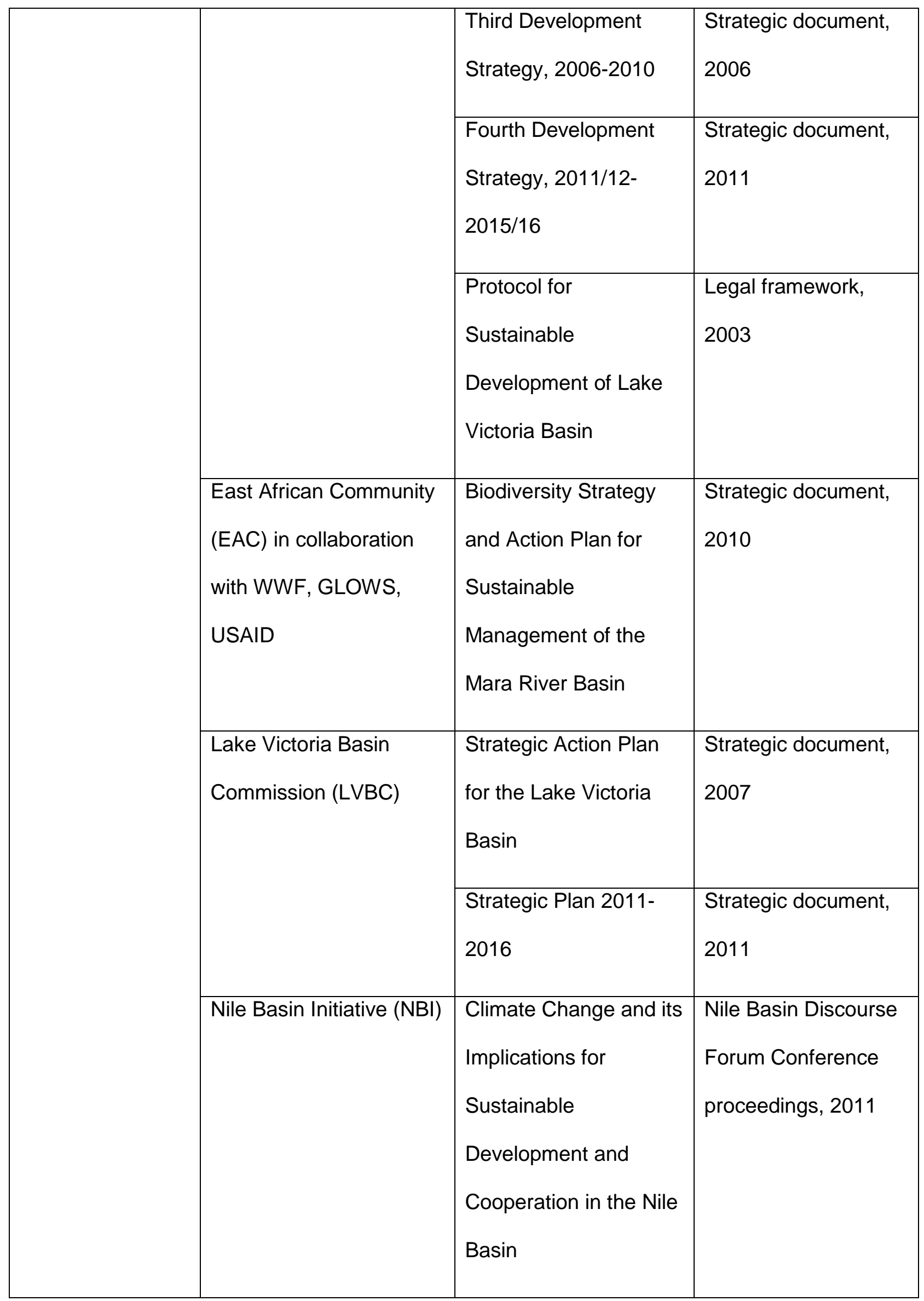




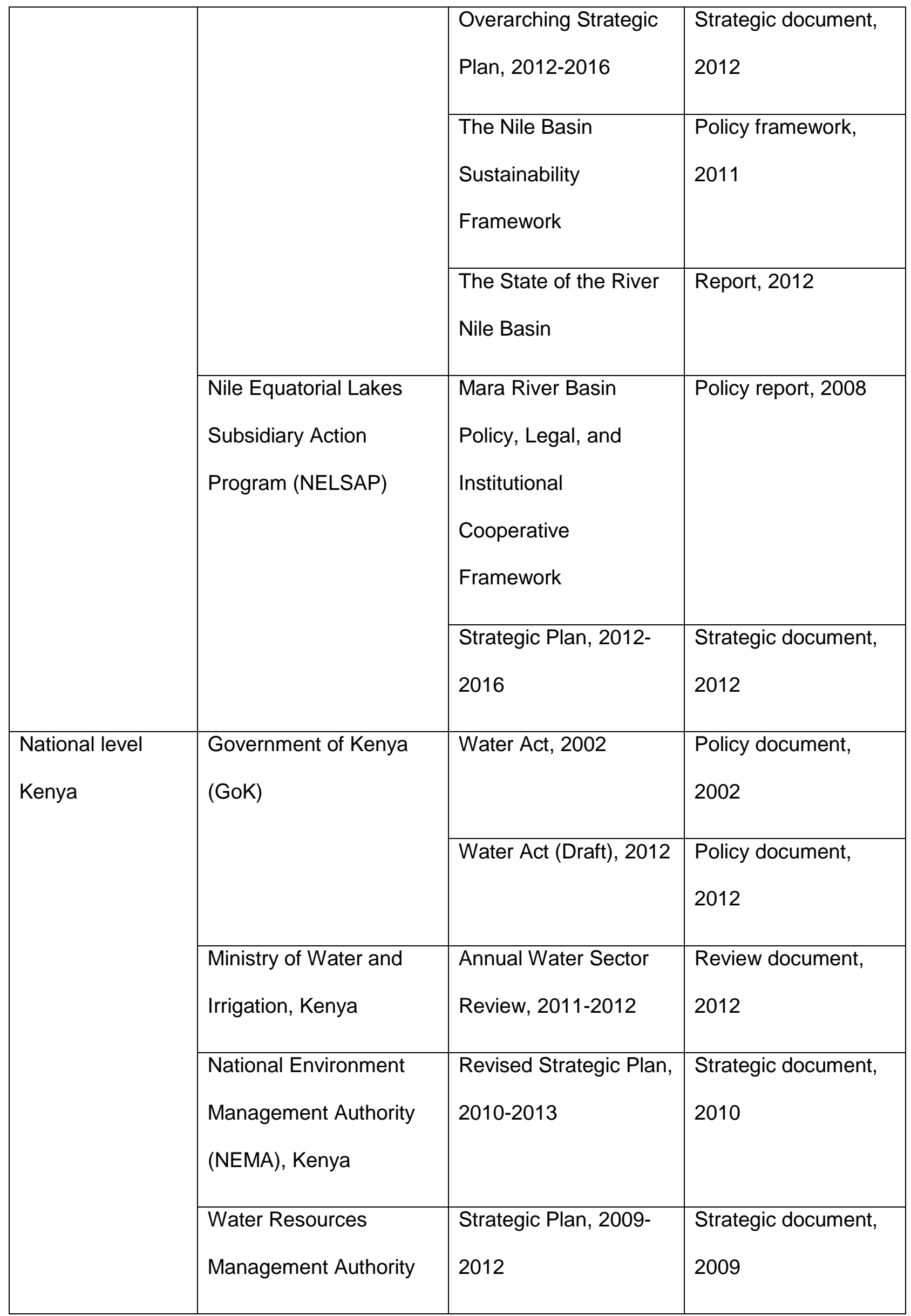




\begin{tabular}{|c|c|c|c|}
\hline & (WRMA), Kenya & & \\
\hline \multirow[t]{3}{*}{$\begin{array}{l}\text { National level } \\
\text { Tanzania }\end{array}$} & $\begin{array}{l}\text { The United Republic of } \\
\text { Tanzania/ Government } \\
\text { of Tanzania (GoT) }\end{array}$ & $\begin{array}{l}\text { The Water Resources } \\
\text { Management Act, } 2009\end{array}$ & $\begin{array}{l}\text { Policy document, } \\
2009\end{array}$ \\
\hline & $\begin{array}{l}\text { Ministry of Water and } \\
\text { Irrigation, Tanzania }\end{array}$ & $\begin{array}{l}\text { National Water Sector } \\
\text { Development Strategy, } \\
2006-1015\end{array}$ & $\begin{array}{l}\text { Strategic document, } \\
2006\end{array}$ \\
\hline & $\begin{array}{l}\text { Ministry of Water and } \\
\text { Livestock Development, } \\
\text { Tanzania }\end{array}$ & $\begin{array}{l}\text { National Water Policy, } \\
2002\end{array}$ & $\begin{array}{l}\text { Policy document, } \\
2002\end{array}$ \\
\hline \multirow[t]{5}{*}{$\begin{array}{l}\text { Multilateral and } \\
\text { bilateral donors }\end{array}$} & $\begin{array}{l}\text { United States Agency } \\
\text { International } \\
\text { Development (USAID) }\end{array}$ & $\begin{array}{l}\text { Water and } \\
\text { Development Strategy, } \\
\text { 2013-2018 }\end{array}$ & $\begin{array}{l}\text { Strategic document, } \\
2013\end{array}$ \\
\hline & $\begin{array}{l}\text { United Nations } \\
\text { Environment Program } \\
\text { (UNEP) }\end{array}$ & $\begin{array}{l}\text { Water Policy and } \\
\text { Strategy, 2007-2012 }\end{array}$ & $\begin{array}{l}\text { Policy document, } \\
2007\end{array}$ \\
\hline & World Bank & $\begin{array}{l}\text { Water Resources } \\
\text { Sector Strategy }\end{array}$ & $\begin{array}{l}\text { Strategic document, } \\
2004\end{array}$ \\
\hline & & $\begin{array}{l}\text { Toward a Green, } \\
\text { Clean, and Resilient } \\
\text { World for all. } \\
\text { Environmental Strategy } \\
2012-2022\end{array}$ & $\begin{array}{l}\text { Strategic document, } \\
2012\end{array}$ \\
\hline & & $\begin{array}{l}\text { Making Sustainable } \\
\text { Commitments. An }\end{array}$ & $\begin{array}{l}\text { Strategic document, } \\
2001\end{array}$ \\
\hline
\end{tabular}




\begin{tabular}{|l|l|l|l|}
\hline & & $\begin{array}{l}\text { Environmental Strategy } \\
\text { for the World Bank }\end{array}$ & \\
\hline Civil society & $\begin{array}{l}\text { Mara River Water } \\
\text { Resources Users' }\end{array}$ & $\begin{array}{l}\text { Strategic Plan 2011- } \\
\text { Association }\end{array}$ & Strategic document, \\
& & 2011 \\
\hline
\end{tabular}

Table 1: Policy documents included in the discourse analysis on WRM, climate change and water security showing the authors (actors), type of actor (policy level) and title, type and year of publication of the document.

\section{Annex II - List of Interview participants}

\begin{tabular}{|l|l|}
\hline Short ID & Participant Information \\
\hline Donor1 (a) & Technical Advisor, Donor Agency 1 \\
\hline Donor1 (b) & Senior advisor, Donor Agency 1 \\
\hline Donor1 (c) & Technical Advisor, Donor Agency 1 \\
\hline Donor1 (d) & Project Director, Donor Agency 1 \\
\hline Donor1 (e) & Programme Officer, Donor Agency 1 \\
\hline Donor2 & Policy Advisor, Donor Agency 2 \\
\hline Donor3 & Senior policy advisor, Donor Agency 3 \\
\hline IC2 & International consultant \\
\hline IC3 & International consultant \\
\hline IC4 & International Consultant \\
\hline
\end{tabular}




\begin{tabular}{|l|l|}
\hline INGO1 (a) & Senior policy advisor, International NGO 1 \\
\hline INGO1 (b) & Technical Expert, International NGO1 \\
\hline INGO1 (c) & Programme Manager, International NGO 1 \\
\hline INGO2 (a) & Technical Coordinator, International NGO 2 \\
\hline INGO2 (b) & Senior advisor, International NGO 3 \\
\hline INGO3 & Programme Officer, International NGO 4 \\
\hline INGO4 & Programme Manager, International \\
\hline Journalist & Organisation \\
\hline KE Consult1 & Journalist \\
\hline KE Gov (a) & Researcher, Kenyan University \\
\hline KE Gov (c) & Programme Manager, Ministry of Water and \\
\hline KE NGO1 & Irrigation, Government of Kenya \\
\hline & Senior policy advisor, Ministry of Water and \\
\hline Irrigation, Government of Kenya \\
\hline
\end{tabular}




\begin{tabular}{|l|l|} 
LVBC(a) & $\begin{array}{l}\text { Policy advisor, Lake Victoria Basin } \\
\text { Commission }\end{array}$ \\
\hline LVBC(b) & $\begin{array}{l}\text { Senior policy advisor, Lake Victoria Basin } \\
\text { Commission }\end{array}$ \\
\hline NBI (a) & Technical expert, Nile Basin Initiative \\
\hline NBI (b) & Senior policy advisor, Nile Basin Initiative \\
\hline NBI (c) & Technical expert, Nile Basin Initiative \\
\hline NBI (d) & Senior economic advisor, Nile Basin Initiative \\
\hline NBI (e) & Programme Manager, Nile Basin Initiative \\
\hline TZ Gov (a) & Senior policy advisor, Ministry of Water, \\
\hline TZ Gov (b) & Government of Tanzanian \\
\hline UG Gov (a) & Technical Expert, Ministry of Water, \\
\hline UG Gov (b) & Government of Tanzanian \\
\hline & Programme Officer, Vice President Office, \\
\hline Uganda \\
\hline
\end{tabular}

\section{REFERENCES}

Adger, W Neil, Arnell, Nigel W, \& Tompkins, Emma L. (2005). Successful adaptation to climate change across scales. Global Environmental Change, 15(2), 77-86.

Adger, W. Neil, Benjaminsen, T. A., Brown, K., \& Svarstad, H. (2001). Advancing a political ecology of global environmental discourses. Development and Change, 32(4), 681715. doi: Doi 10.1111/1467-7660.00222 
Adger, W. Neil, Huq, Saleemul, Brown, Katrina, Conway, Declan, \& Hulme, Mike. (2003). Adaptation to climate change in the developing world. Progress in Development Studies, 3(3), 179-195.

Barnett, Jon, \& O'Neill, Saffron. (2010). Maladaptation. Global Environmental Change, 20(2), 211-213.

Berhanu, Belete, Seleshi, Yilma, Amare, Melkamu, \& Melesse, Assefa M. (2016). UpstreamDownstream Linkages of Hydrological Processes in the Nile River Basin Landscape Dynamics, Soils and Hydrological Processes in Varied Climates (pp. 207-223): Springer.

Beyene, Tazebe, Lettenmaier, D. P., \& Kabat, P. (2010). Hydrologic impacts of climate change on the Nile River Basin: implications of the 2007 IPCC scenarios. Climatic Change, 100, 433-461.

Biswas, Asit K. (2004). Integrated Water Resources Management: A Reassessment. Water International, 29(2), 248-256.

Boko, M,, Niang, I., Nyong, A., Vogel, C., Githeko, A., Medany, M., Osman-Elasha, B., Tabo, R., and Yanda, P. (2007). Africa. In M. L. Parry, O. F. Canziani, J. P. Palutikof, P. J. v. d. Linden, C. E. Hanson \& et. al. (Eds.), Climate Change 2007: Impacts, Adaptation and Vulnerabilities. Contribution of Working Group II to the Fourth Assessment Report of the Intergovernmental Panel on Climate Change (pp. 433-467). Cambridge.

Boykoff, Maxwell T. (2008). The cultural politics of climate change discourse in UK tabloids. Political Geography, 27(5), 549-569.

Buzan, Barry, Wæver, Ole, \& Wilde, Jaap de. (1998). Security : a new framework for analysis. Boulder, Colo. ; London: Lynne Rienner.

Caravani, A., Barnard, S., Nakhooda, S., \& Schalatek, L. (2014). Climate Finance Thematic Briefing: Adaptation Finance. Climate Finance Fundamentals, 3.

Cascao, Ana Elisa. (2008). Ethiopia - challenges to Egyptian hegemony in the Nile Basin. Water Policy, 10(S2), 1-18.

Cascão, Ana Elisa, \& Nicol, Alan. (2016). GERD: new norms of cooperation in the Nile Basin? Water International, 1-24.

Christensen, J.H., Hewitson, Bruce, Busuioc, Aristita, Chen, Anthony, Gao, Xuejie, Held, R, ... Laprise, René. (2007). Regional climate projections. Climate Change, 2007: The Physical Science Basis. Contribution of Working group I to the Fourth Assessment Report of the Intergovernmental Panel on Climate Change, University Press, Cambridge, Chapter 11, 847-940.

CIA. (2015). The World Factbook. Retrieved 17.03.2016, 2016, from https://http://www.cia.gov/library/publications/resources/the-world-factbook/

Conway, Declan. (2005). From headwater tributaries to international river: Observing and adapting to climate variability and change in the Nile basin. Global Environmental Change-Human and Policy Dimensions, 15(2), 99-114. doi: Doi 10.1016/J.Gloenvcha.2005.01.003

Conway, Declan, Allison, Edward, Felstead, Richard, \& Goulden, Marisa. (2005). Rainfall variability in East Africa: implications for natural resources management and livelihoods. Philosophical Transactions of the Royal Society of London A: Mathematical, Physical and Engineering Sciences, 363(1826), 49-54.

Conway, Declan, Persechino, Aurelie, Ardoin-Bardin, Sandra, Hamandawana, Hamisai, Dieulin, Claudine, \& Mahe, Gil. (2009). Rainfall and water resources variability in subsaharan Africa during the 20th century. Working Paper. Tyndall Centre for Climate Change Research. 
Cooley, Heather, Christian-Smist, Juliet, Gleick, Peter H, Allen, Lucy, \& Cohen, Michael. (2009). Understanding and Reducing the Risks of Climate Change for Transboundary Waters. Oakland: Pacific Institute.

Dayton, Bruce W. (2000). Policy Frames, Policy Making and the Global Climate Change Discourse. In H. Addams \& J. Proops (Eds.), Social Discourse and Envrionment Policy. An Application of Q Methodology. Cheltenham, Northampton (MA).

Decalo, Samuel. (1992). The process, prospects and constraints of democratization in Africa. African Affairs, 91(362), 7-35.

Dessu, Shimelis Behailu, \& Melesse, Assefa Mekonnen. (2013). Impact and uncertainties of climate change on the hydrology of the Mara River basin, Kenya/Tanzania. Hydrological Processes, 27(20), 2973-2986. doi: 10.1002/hyp.9434

Di Baldassare, Giuliano, Elshamy, Mohamed, van Griensven, Ann, Soliman, Eman, Kigobe, Max, Ndomba, Preksedis, . . . Uhlenbrook, Stefan. (2011). Future hydrology and climate in the River Nile basin: a review. Hydrological Science Journal - Journal Des Sciences Hydrologiques, 56(2), 199-211.

Doulton, H., \& Brown, K. (2009). Ten years to prevent catastrophe? Discourses of climate change and international development in the UK press. Global Environmental Change-Human and Policy Dimensions, 19(2), 191-202. doi: Doi 10.1016/J.Gloenvcha.2008.10.004

Dryzek, John S. (2013). The politics of the Earth : environmental discourses (3rd ed. ed.). Oxford: Oxford University Press.

EAC. (2011). 4th EAC Development Strategy (2011/12-2015/16). Deepening and Accelerating Integration. Arusha, Tanzania: East African Community.

El Bastawesy, Mohammed, Gabr, Safwat, \& Mohamed, Ihab. (2015). Assessment of hydrological changes in the Nile River due to the construction of Renaissance Dam in Ethiopia. The Egyptian Journal of Remote Sensing and Space Science, 18(1), 65-75.

El Bastawesy, Mohammed, Gabr, Safwat, \& White, Kevin. (2013). Hydrology and geomorphology of the Upper White Nile lakes and their relevance for water resources management in the Nile basin. Hydrological Processes, 27(2), 196-205. doi: 10.1002/hyp.9216

Elhance, Arun P. (1999). Hydropolitics in the Third World. Conflict and Cooperation in International River Basins. Washington, D.C.

Gerlak, Andrea K, \& Mukhtarov, Farhad. (2016). Many Faces of Security: Discursive Framing in Cross-border Natural Resource Governance in the Mekong River Commission. Globalizations, 1-22.

Gleick, Peter H. (1991). The vulnerability of runoff in the Nile Basin to climatic changes. Environmental Professional, 13(1), 66-73.

Gleick, Peter H, Biberstine, J., Buckingham, A., Dearness, T., Highsmith, A., McTopy, J., ... Stevens, L. (1997). Climate change and water resources. Journal American Water Works Association, 89(11), 107-110.

Goulden, Marisa, \& Conway, Declan. (2008). Cooperation and Adaptation to Climate Change in the River Nile Basin. Paper presented at the presented at the Nile Basin Discourse Forum 2008, Khartoum, Sudan.

Goulden, Marisa, Conway, Declan, \& Persechino, Aurelie. (2009). Adaptation to climate change in international river basins in Africa: a review. Hydrological Science Journal - Journal Des Sciences Hydrologiques, 54(5), 805-828.

Government of Kenya. (2010). National Climate Change Response Strategy. Nairobi, Kenya.

Government of Kenya. (2013). Annual Water Sector Review 2011-2012. Nairobi, Kenya: Ministry of Water and Irrigation. 
Government of Tanzania. (2002). National Water Policy. Dar es Salaam, Tanzania: Ministry of Water and Livestock Development.

Government of Tanzania. (2008). National Water Sector Development Strategy 2006-2015. Dar es Salaam, Tanzania: Ministry of Water and Irrigation.

Hajer, Maarten. (1995). The Politics of Environmental Discourses. Ecological Modernization and the Policy Process. Oxford: Clarendon Press.

Hajer, Maarten, \& Versteeg, Wytske. (2005). A decade of discourse analysis of environmental politics: Achievements, challenges, perspectives. Journal of Environmental Policy \& Planning, 7(3), 175-184. doi: 10.1080/15239080500339646

Hissen, Nina. (2014). The Influence of Policy Discourses on Multilevel Water Governance. A Case Study from the Equatorial Nile Basin. (PhD), University of East Anglia, Norwich, UK.

Hulme, Michael. (1990). Global climate change and the Nile Basin. In P. P. Howell \& J. A. Allan (Eds.), The Nile, Resource Evaluation, Resource Management, Hydropolitics and legal issues (pp. 59-82). London: SOAS-RGS.

Hulme, Michael. (2009). Why we disagree about climate change. Understanding controversey, inaction and opportunity. Cambridge.

Keith, Bruce, Epp, Kevin, Houghton, Michael, Lee, Jonathan, \& Mayville, Robert. (2014). Water As A Conflict Driver: Estimating The Effects Of Climate Change And Hydroelectric Dam Diversion On Nile River Stream Flow During The 21st Century. Center for Nation Reconstruction and Capacity Development, 73.

Kizza, M., Rodhe, A., Xu, C. Y., Ntale, H. K., \& Halldin, S. (2009). Temporal rainfall variability in the Lake Victoria Basin in East Africa during the twentieth century. Theoretical and Applied Climatology, 98(1-2), 119-135. doi: Doi 10.1007/S00704-008-0093-6

Kundzewicz, Zbigniew W, Kanae, Shinjiro, Seneviratne, Sonia I, Handmer, John, Nicholls, Neville, Peduzzi, Pascal, ... Mach, Katharine. (2014). Flood risk and climate change: global and regional perspectives. Hydrological Sciences Journal, 59(1), 1-28.

Lankford, Bruce, Bakker, Karen, Zeitoun, Mark, \& Conway, Declan (Eds.). (2013). Water security : principles, perspectives and practices.

Litfin, Karen. (1994). Ozone discourse : science and politics in global environmental cooperation. New York ; Chichester: Columbia University Press.

LVBC. (2011). Lake Victoria Basin Commission Strategic Plan (2011-2016). Kisumu, Kenya: Lake Victoria Basin Commission.

Milly, P. C. D. , Dunne, K. A., \& Vecchia, A. V. (2005). Global pattern of trends in streamflow and water availability in a changing climate. Nature, 438, 347-350.

Molle, François. (2008). Nirvana Concepts, Narratives and Policy Models: Insights from the Water Sector. Water Alternatives, 1(1), 131-156.

Mosse, David, \& Lewis, David. (2006). Theoretical Approaches to Brokerage and Translation in Development. In D. Lewis \& D. Mosse (Eds.), Development Brokers and Translators. The Ethnography of Aid and Agencies. Bloomfield.

MRWUA. (2011). Mara River Water Users Association Strategic Plan 2011-2013. Narok, Kenya: Mara River Water Users Associations (MRWUA).

NBI. (2011). The Nile Basin Sustainability Framework. The Nile Basin Initiative's approach to basin sustainability. Entebbe, Uganda: Nile Basin Initiative.

NBI. (2012). State of the River Nile Basin. Entebbe, Uganda.

NELSAP. (2012). Nile Equatorial Lakes Subsidiary Action Program. Strategic Plan 20122016. Kigali, Rwanda: Nile Equatorial Lakes Subsidiary Action Program.

NEMA. (2010). Revised Strategic Plan 2010-2013. Nairobi, Kenya: National Environment Management Authority. 
Niang, I., Ruppel, O. C., Abdrabo, M. A., Essel, A., Lennard, C., Padgham, J., \& Urquhart, P. (2014). Africa. In V. R. Barros, C. B. Field, D. J. Dokken, M. D. Mastrandrea, K. J. Mach, T. E. Bilir, M. Chatterjee, K. L. Ebi, Y. O. Estrada, R. C. Genova, B. Girma, E. S. Kissel, A. N. Levy, S. MacCracken, P. R. Mastrandrea \& L. L. White (Eds.), Climate Change 2014: Impacts, Adaptation, and Vulnerability. Part B: Regional Aspects. Contribution of Working Group II to the Fifth Assessment Report of the Intergovernmental Panel of Climate Change. Cambridge, United Kingdom and New York, NY, USA: Cambridge University Press.

Nicol, Alan, \& Cascao, Ana Elisa. (2011). Against the flow- new power dynamics and upstream mobilisation in the Nile Basin. Review of African Political Economy, 38(128), 317-325.

Nile Basin Development Forum. (2011). Kigali Declaration. Climate Change and its Implications for Sustainable Development and Cooperation in the Nile Basin. Kigali, Rwanda.

O'Brien, Karen, Eriksen, Siri, Nygaard, Lynn P, \& Schjolden, Ane. (2007). Why different interpretations of vulnerability matter in climate change discourses. Climate Policy, 7(1), 73-88.

Potter, Jonathan, \& Wetherell, Margaret. (1994). Analyzing Discourse. In A. Bryman \& R. G. Burgess (Eds.), Analzying Qualitative Data (pp. 47-66). London New York.

Saravanan, V. S., McDonald, Geoffrey T., \& Mollinga, Peter P. (2009). Critical review of Integrated Water Resources Management: Moving beyond polarised discourse. Natural Resources Forum, 33(1), 76-86. doi: 10.1111/j.1477-8947.2009.01210.x

Seneviratne, Sonia I, Nicholls, Neville, Easterling, David, Goodess, CM, Kanae, Shinjiro, Kossin, James, ... Rahimi, M. (2012). Changes in climate extremes and their impacts on the natural physical environment. Managing the risks of extreme events and disasters to advance climate change adaptation, 109-230.

SIDA. (2010). Development Cooperation Sweden and Kenya. Natural Resources and Environment.

Stetter, Stephan, Herschinger, Eva, Teichler, Thomas, \& Albert, Mathias. (2011). Conflicts about water: Securitizations in a global context. Cooperation and Conflict, 46(4), 441-459. doi: 10.1177/0010836711422462

Sutcliffe, J. V., \& Petersen, G. (2007). Lake Victoria: derivation of a corrected natural water level series / Lac Victoria: dérivation d'une série naturelle corrigée des niveaux d'eau. Hydrological Sciences Journal, 52(6), 1316-1321. doi: 10.1623/hysj.52.6.1316

Taye, Meron Teferi, Willems, Patrick, \& Block, Paul. (2015). Implications of climate change on hydrological extremes in the Blue Nile basin: a review. Journal of Hydrology: Regional Studies, 4, 280-293.

The Guardian. (2011, 08.07.2011). Horn of Africa: From one drought to another. Editorial, Editorial, The Guardian, p. 38.

The Guardian. (2016). As Mozambique's Rivers dry up, the hopes of a harvest evaporate too. Retrieved from http://www.theguardian.com/globaldevelopment/2016/feb/17/mozambique-drought-hopes-harvest-evaporate

United Nations. (2015). World Population Prospects: The 2015 Revision, Key Findings and Advance Tables. New York: Department of Economic and Social Affairs, Population Division.

United Republic of Tanzania. (2007). National Adaptation Programme of Action (NAPA). Dar es Salaam, Tanzania.

USAID. (2013). Water and Development Strategy. Washington, D.C., USA: United States Agency International Development. 
Warner, J. E. (2011). Flood planning : the politics of water security. London: I. B. Tauris.

Waterbury, John. (2002). The Nile Basin. National Determinants of Collective Action: New Haven, London.

World Bank. (2004). Water Resources Strategy. Strategic Directions for World Bank Engagement. Washington, D.C., USA.

World Bank. (2012). Project Information Document unpublished.

WREM. (2008). Policy, Legal, and Institutional Cooperative Framework. Mara River Basin Transboundary Integrated Water Resources Management and Development Project. Final Technical Report. Atlanta: Water Resources and Energy Management International Inc.,.

WRMA. (2009a). Lake Victoria South. Catchment Area Management Strategy. Kisumu: Water Management Authority (WRMA).

WRMA. (2009b). Strategic Plan 2009-2012. Nairobi, Kenya: Water Resources Management Authority.

Zeitoun, Mark, Goulden, M., \& Tickner, D. (2013). Current and future challenges facing transboundary river basin management. Wiley Interdisciplinary Reviews-Climate Change, 4(5), 331-349. doi: Doi 10.1002/Wcc.228

Zeitoun, Mark, \& Warner, Jeroen. (2006). Hydro-hegemony - a Framework for Analysis of Trans-boundary Water Conflicts. Water Policy, 8, 435-460. 